\title{
LES ARCHIVES
}

DE LA

\section{VILLE DE STRASBOURG}

ANTERIEURES A 1790. 



\section{LES ARCHIVES}

DE LA

\section{VILLE DE STRASBOURG}

ANTÉRIEURES A 1790.

APERÇU SOMMAIRE

PAR

J. C. BRUCKER

ARGHIISTE DE LA VILLE.

STRASBOURG

MIPRIMERIE DE J. H. EDOUARD HEITZ, RUE DE L'OUTRE, 5.

1873. 
